\title{
The right to strike
}

The past few months have seen increasing numbers of strikes by healthcare workers who belong to the National Education, Health and Allied Workers' Union (NEHAWU). In this issue of SAMJ, Ames Dhai and Safia Mahomed ${ }^{[1]}$ examine the right to strike among workers in the hospital sector, describing the recent situation as 'South Africa's healthcare battlefield'.

The hospital sector is regarded by the International Labour Organization as an 'essential service', where the 'right to strike may be subject to major restrictions or even prohibitions'. While the striking workers' grievances may have been real, their behaviour during the strike was totally unacceptable. Headlines such as 'Striking NEHAWU workers scatter rubbish in hospital's foyer ${ }^{[2]}$ and 'Hospital chaos: Charlotte Maxeke workers claim victory ahead of meeting, ${ }^{[3]}$ along with photographs of toyi-toying protestors in hospital corridors strewn with rubbish, with frightened patients trying to negotiate the rubbish, some in wheelchairs, do little to endear the protestors to the public. Essentially, the hospital was shut, with no emergency access, doctors prevented from coming to work, nurses not at their stations and patients unable to access the care to which they are entitled. Patient safety was at stake, with patients reportedly locked into the nuclear medicine department for their own safety.

In May this year, Laratong Hospital in the West Rand saw surgery cancelled ${ }^{[4]}$ as workers under various unions including the Democratic Nursing Organisation of South Africa, the Public Servants Association and NEHAWU went on strike over nonpayment of bonuses. Inpatients were left without food and those staff who were working had to work double shifts as no one was allowed in or out of the hospital.

As a country we are used to strikes, and sadly we are used to violent protest action. But this behaviour, in the face of already failing health services, must leave us all appalled. Healthcare is a universal right. Many of the hospitals involved are teaching hospitals, meaning that the strike action has also potentially affected training of future healthcare workers in the country. The denial of healthcare resulting from these strikes leads directly to patient suffering, not to mention the damage to government property, which has direct consequences on healthcare financing in affected regions.

With little action by the authorities and a somewhat limp reaction by our Minister of Health, who simply refused to acknowledge the strike, the danger is that this kind of action will become the norm. As our healthcare services fall into further disarray as a result of either lack of finance or inability to use allocated funds effectively, we are likely to see more action of this kind. Laws must be implemented and enforced. We cannot allow anarchy of this kind in our healthcare services.

\section{Bridget Farham \\ Editor \\ ugqirha@iafrica.com}

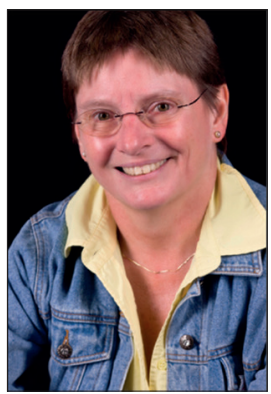

1. Dhai A, Mahomed S. The National Education, Health and Allied Workers' Union (NEHAWU) strikes South Africa's healthcare battlefield. S Afr Med J 2018;108(8):632-633. DOI:10.7196/SAMJ.2018 v108i8.13458

2. Times Live. https://www.timeslive.co.za/news/south-africa/2018-04-26-striking-nehawu-workersscatter-rubbish-in-hospitals-foyer/ (accessed 16 July 2018).

3. Times Live. https://www.timeslive.co.za/news/south-africa/2018-06-01-hospital-chaos-charlottemaxeke-workers-claim-victory-ahead-of-meeting/ (accessed 16 July 2018).

4. Sowetan Live. https://www.sowetanlive.co.za/news/south-africa/2018-05-31-hospital-cans-surgeriesdue-to-strike/ (accessed 16 July 2018).

S Afr Med J 2018;108(8):605. DOI:10.7196/SAMJ.2018.v108i8.13542 